\title{
REVIEW
}

\section{Advances in Genomic Research on Hepatitis C Virus with a Useful Tool, Replicon System}

\author{
Mitsuyasu Nakamura, Hidetsugu Saito, and Toshifumi Hibi \\ Division of Gastroenterology and Hepatology, Department of Internal Medicine, \\ School of Medicine, Keio University, Tokyo, Japan \\ (Received for publication on August 31, 2007) \\ (Revised for publication on December 3, 2007) \\ (Accepted for publication on January 17, 2008)
}

\begin{abstract}
The research for hepatitis $\mathrm{C}$ virus (HCV) has long delayed by missing of in vitro culture system. Since the development of replicon system, a replication system of subgenomic HCV RNAs in a hepatoma cell line, has been reported, many virological and clinical findings have been discovered. Recently, in addition of subgenomic replication system, hepatitis C virus full-length RNA replication has been possible, and a few cell culture systems producing viral particles have been produced. These developments enabled us to investigate the life cycle or intracellular circumstance of HCV production. By screening of newly synthesized drugs with this replicon system, several possible medicines have been established and clinical researches are now running. Among them, VX950 and SCH503034 are nearest to clinical use. Other possible agents for reducing viral replication such as cyclophyllin inhibitors, inhibitors of sphingomyelin synthesis, HMG-CoA reductase inhibitors, or RNAdependent RNA polymerase inhibitors have been also investigated. Furthermore the mechanism for development of hepatocellular carcinoma in the HCV infected liver has been vigorously studied using the HCV replicon system. (Keio J Med 57 (2) : 75-83, June 2008)
\end{abstract}

Key words: hepatitis C virus, replicon, VX950, lipid raft, Rb

\section{Introduction}

Hepatitis $\mathrm{C}$ virus (HCV) belongs to the Hepacivirus genus of the Falviviridae family. It is a spherical particle, 55 to $65 \mathrm{~nm}$ in diameter, with an envelope, and consists of the genome of a $9.6-\mathrm{kb}$ plus strand RNA. It has short untranslated regions at both the 5'- and 3'- termini, and the middle region, which accounts for about $95 \%$ of the whole genome, encodes a precursor protein consisting of roughly 3,010 amino acid residues. The coding regions of viral structural proteins such as core as well as E1 and $\mathrm{E} 2$ are located at the $\mathrm{N}$-terminus, while the non-structural proteins NS2, NS3, NS4A, NS4B, NS5A, and NS5B are situated at the middle region near the $\mathrm{C}$-terminus. ${ }^{1,2}$ $\mathrm{HCV}$ is categorized according to 6 genotypes and is further classified into several subtypes.

$\mathrm{HCV}$ is transmitted through blood and it often causes persistent infection. Post-infection symptoms are often mild. Infected subjects develop chronic hepatitis from a carrier state, and eventually, liver cirrhosis and hepatocellular carcinoma (HCC) over period of up to 30 or more years. In Japan, it is estimated that there are 1.5 million HCV-infected people, and infection is more common among the elderly than among younger individuals. About 30,000 patients die of $\mathrm{HCC}$ associated with $\mathrm{HCV}$ infection, and $\mathrm{HCC}$ is currently ranked as the fourth leading cause of death. The ideal treatment is eradication of HCV from the body, and a combination of interferon (IFN) and ribavirin (RBV) is the current mainstream regimen. $^{3}$

Presence of the hypervariable region (HVR) at the $\mathrm{N}$-terminus of the $\mathrm{E} 1 / \mathrm{E} 2 / \mathrm{NS} 1$ regions which is responsible for surface structure, is thought to play a role in persistent HCV infection. Nevertheless, heterogeneity of the HVR does not correlate with hepatitis activity. ${ }^{4}$ With regard to $\mathrm{HCV}$ eradication by IFN, analysis of the viral

Corresponding Author: Hidetsugu Saito MD, 35 Shinano-machi, Shinjuku-ku, Tokyo 160-8582, Japan TEL: 3-3353-1211 Ext 62894, FAX: 3-3351-8705, E-mail: hsaito@sc.itc.keio.ac.jp 


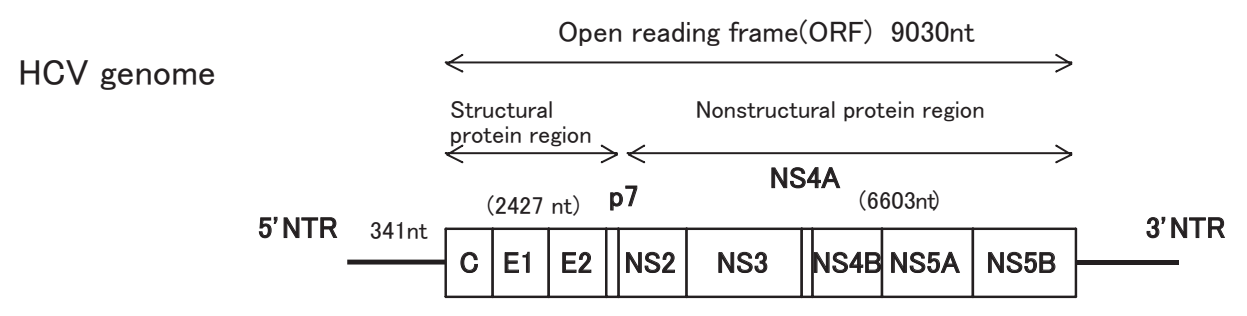

HCV full-length replicon

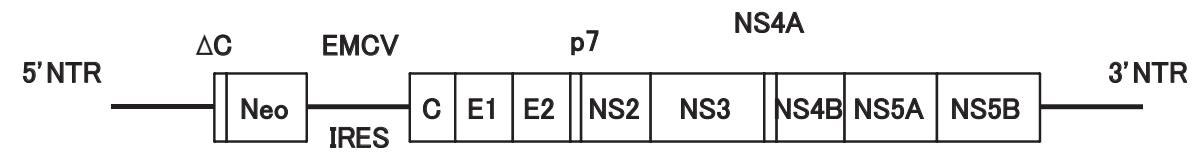

HCV subgenomic replicon

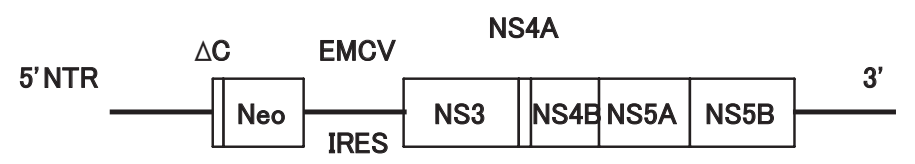

Fig. 1 The structure of HCV genome, that of HCV full-length replicon and subgenomic replicon

sensitivity to IFN revealed the presence of the IFN sensitivity-determining region (ISDR), which influences sensitivity to IFN, at the center of NS5A, a non-structural protein of HCV. ${ }^{5,6}$ Meanwhile, the number of amino acid mutation in the ISDR has been reported to have a significant negative correlation with the amount of $\mathrm{HCV}$ RNA. $^{7}$

Since the replicon system has been developed, virological aspects of HCV including its life cycle were uncovered, and development of this system and more recently of a cell culture system has enabled the development of $\mathrm{HCV}$-specific inhibitors and quantitative measurement of antiviral potency. Many of the newly developed inhibitors are under investigation in pre-clinical and clinical trials, and these specific inhibitors will improve treatment opportunities of patients with chronic hepatitis C, especially in difficult-to-treat patients including patients who do not respond to Peg-IFN and RBV combination therapy. In this mini-review, we introduced the HCV replicon system and summarized newly developed virological and clinical discoveries, following to the development of replicon and cell culture systems.

\section{Cells Replicating an $\mathrm{HCV}$ Gene-replication Unit (replicon)}

In 1989, a group led by Houghton et al. at Chiron (a subsidiary of Novartis AG, Basel, Switzerland) succeeded in cloning the HCV genome for the first time. ${ }^{8}$ In 1997, Rice et al. successfully established an infectious clone from cloned cDNA, which induced acute hepatitis in chimpanzees. ${ }^{9}$ Chimpanzees which are the only reliable animal model for HCV infection, are difficult to obtain and expensive to maintain and are therefore not suitable for drug screening studies. As a result, the development of efficient replication systems in cultured cells has been eagerly anticipated.

In 1999, Bartenshalger et al. established the first culture system in which HCV subgenomic RNA replicated and maintained itself and in which HCV gene replication was efficiently reproduced. ${ }^{10}$ This system was referred to as an HCV replicon system. The structure of HCV replicon RNA is shown in Fig. 1. In HCV subgenomic RNA, a structural protein region encoding the viral particle is replaced with the code sequence of aminoglycoside phosphotransferase (Neor) that detoxifies neomycin harboring cytotoxicity. The internal ribosome entry site (IRES) derived from encephalomyocarditis virus (EMCV) is inserted at the down-stream region of the Neor gene. Due to this sequence, translation starts within RNA, and non-structural protein, which is located downstream and involved in HCV gene replication, is efficiently translated.

RNA synthesized in vitro can be introduced into HCCderived $\mathrm{HuH7}$ cells, and with RNA introduced cells can be selected with neomycin. The HCV genome sequence that can self-replicate in cells, and cells that enable the self-replication, are selected and replicon cells are thus obtained (Fig. 2). To date, similar replicon cells have been established with several different HCV genome se- 


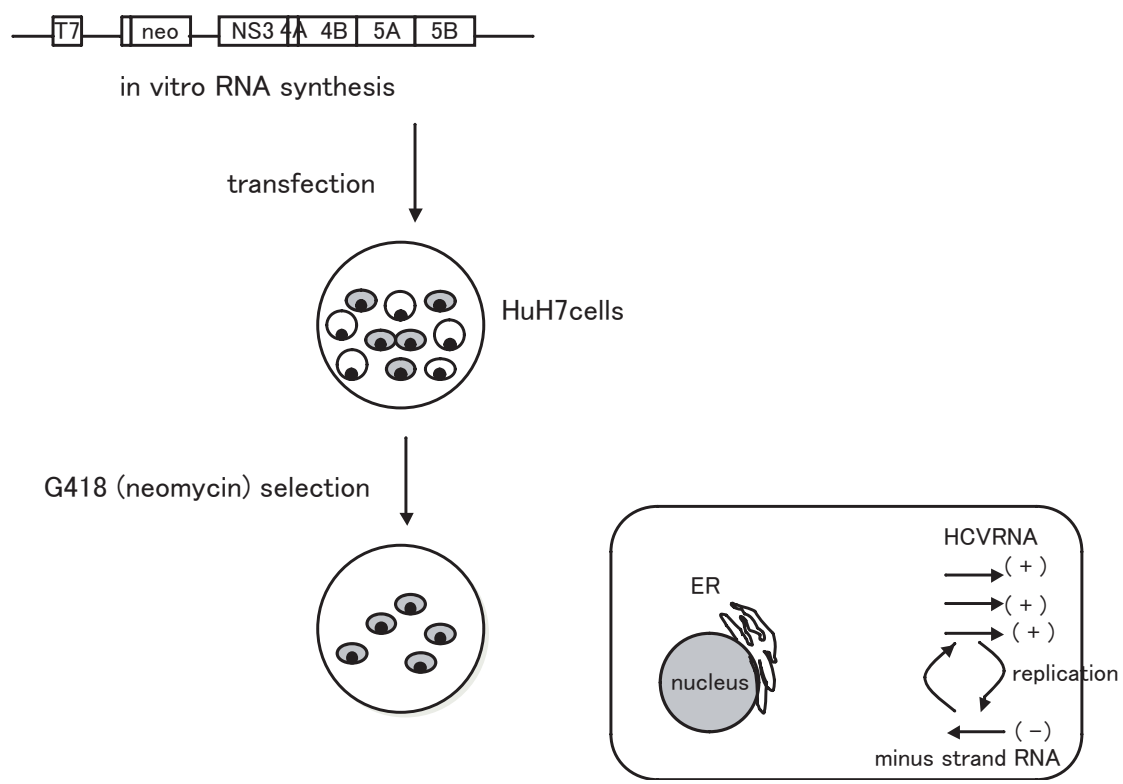

Fig. 2 Outline of HCV replicon system. Subgenomic replicon RNAs are produced from plasmid including T7 promoter by in vitro transcription using T7 RNA polymerase. These RNAs are transfected into the human hepatoma cell line Huh-7. Only cells in which the replicon self-replicates will carry the gene encoding neomycin phosphotransferase, which inactivates G418, to become resistant to G418.

quences. ${ }^{1-13}$ Thus, the development of the HCV replicon system has enabled the analysis of virus genome replication at the cellular level. ${ }^{14}$

\section{Research on the HCV Genome Replication System}

Research on HCV genome replication started with analysis of the RNA genome structure in replicon cells. To date, it has been determined that a phenomenon called adaptive mutation occurs in the RNA genome in cultured cells. ${ }^{15}$ This is presumed to be a result of selected amino acid mutation in HCV protein so that RNA can efficiently replicate and proliferate in cultured cells. The RNA structure required for genome replication has been identified by artificial introduction of mutation (e.g., various deletion mutations) into HCV subgenome RNA. Furthermore, replication systems are currently indispensable for elucidation of the pathogenesis of HCV infection and development of antiviral drugs. We previously found differences in specific sites in the HCV NS5B region between patients that did or did not respond to IFN-RBV combination therapy, ${ }^{16}$ and are now exploring alterations using the replicon system in vitro. ${ }^{17}$

\section{Full-length HCV RNA Replication System}

While the subgenomic replicon in vitro system is used to express non-structural proteins necessary for replication, not only non-structural proteins but also structural proteins are actually expressed in vivo. The influence of $\mathrm{HCV}$ on host cell factors, such as IFN, other cytokines, and signal transduction, are complex events mediated by full-length HCV proteins. Different full-length replicon RNAs have been produced by some research groups. ${ }^{18,19}$ In the full-length HCV RNA replication system, the presence of double strand RNA (dsRNA), consisting of the HCV RNA plus strand and the minus strand, an intermediate replication product, enables easier evaluation of the influence of $\mathrm{HCV}$, including the effect of dsRNA, on host factors, compared with a replicon system with nonstructural regions using a variety of promoters. Since structural proteins are required for the production of viral particles, full-length HCV RNA replication systems have advanced research on in vivo properties of the virus, including packaging, budding, and infection ${ }^{20-24}$ (Fig.3).

\section{Structure of the Replication Complex}

Intracellular environments for HCV RNA synthesis and replication were examined in the subgenome replicon system, and it was found that replicon HCV RNA was localized in the cell membrane structure, especially at endoplasmic reticulum membrane, and partly in the region surrounded by non-structural protein-like lipid membrane, while most of the non-structural protein was present on the cytoplasmic side of the lipid membrane. ${ }^{24}$ This suggests that replicon RNA replicates in a structure surrounded by lipid membrane, i.e. lipid raft. Similar results have also been reported with regard to RNA replication of plant viruses such as bromomosaic virus. Intracellulcar environments surrounded by lipid membrane 


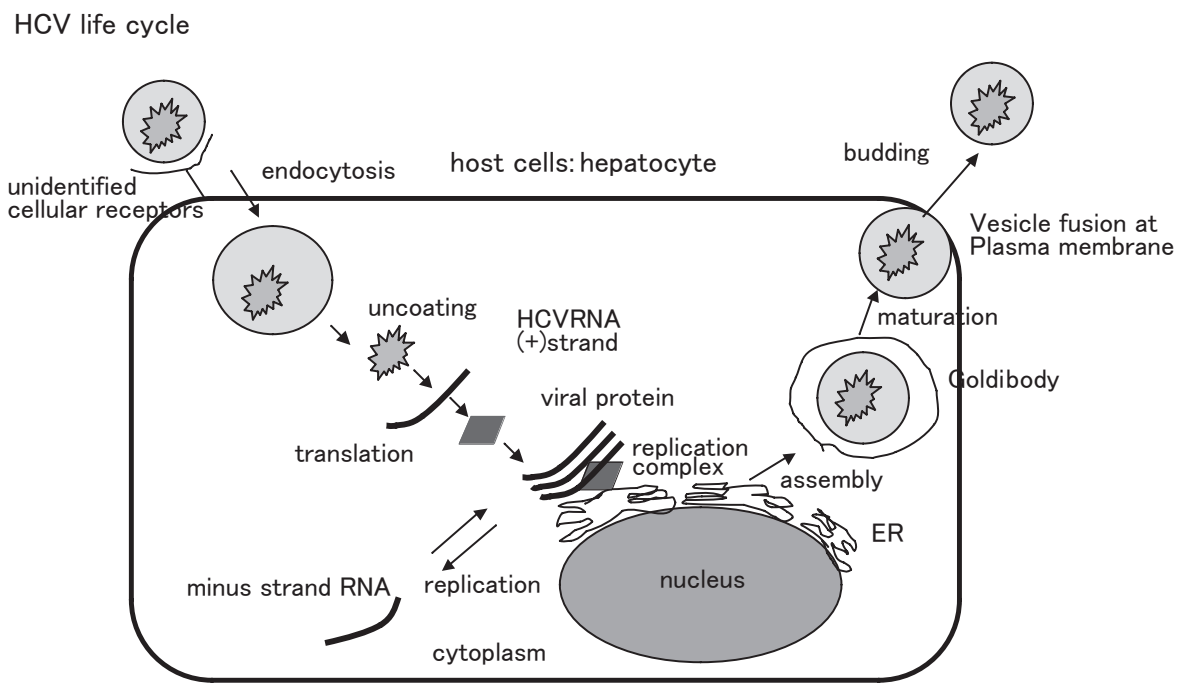

Fig. 3 HCV life cycle

a) Virus binds to host cell receptors (CD81 and other unidentified candidates, such as low density lipoprotein receptor (LDL-R) and scavenger receptor class-B type-I (SR-BI)) and enters by endocytosis.

b) After uncoating nucleocapsid, IRES-mediated translation and polyprotein processing occurs on the endoplasmic reticulum (ER) .

c) RNA replication: formation of a replication complex on the altered ER membrane, and transcription and synthesis of (-) strand RNA, which serves as a template for progeny $(+)$ strand RNA.

d) Packing and assembly: structural protein (E1, E2 and core) and progeny $(+)$ strand RNA assemble.

e) Virion maturation and particle release.

are potentially those for the $\mathrm{HCV}$ genome replication complex. ${ }^{26,27}$

\section{JFH-1 Strain Replicon and Production of Infection Virus Particles}

Wakita et al. cloned an HCV gene from serum of a patient with fulminant hepatitis, a rare complication of type $\mathrm{C}$ chronic hepatitis, and designated it as the JFH-1 strain genotype 2a. Subgenomic ${ }^{28}$ and full-length replicons ${ }^{29}$ were constructed from the JFH-1 strain, and production of viral particles in the culture supernatant of HCV RNA replicating cells was confirmed. In addition, an $\mathrm{HCV}$ culture system with even higher infection efficiency was established by combination of the JFH-1 strain and cured cells established from replicon cell experiments. ${ }^{30,31}$ However, the onset of fulminant hepatitis is extremely rare in even $\mathrm{HCV}$ genotype 2 a cases, suggesting that JFH-1 strain was established from a very rare clinical case. The viral particles released from the JFH-1 replicon can infect chimpanzees but do not cause hepatitis. The establishment of JFH-1 strain which forms infectious viral particles opened a black box of HCV virology and biology. The role of CD81 and heparin sulfate proteoglycan on HCV entry into the cell has been demonstrated using this system recently. ${ }^{31}$ On the other hand, in Japan, the most prevalent HCV subtype is genotype $1 \mathrm{~b}$, and the virus is most resistant to eradication by IFN in patients with this genotype (1b). It is anticipated that a replicon that produces infectious viral particles derived from genotype $1 \mathrm{~b}$ HCV will be established.

\section{Research and Application of Replicons and the Full-length HCV RNA Replication System: Screening of New Drugs with Replicons}

Pegylated-IFN (Peg-IFN) in combination with RBV is the current mainstream treatment for chronic hepatitis $\mathrm{C}$, however, such therapy has several limitations which remain to be overcome. Although viral eradication rates have been improved by the combination of Peg-IFN and RBV compared with IFN monotherapy, the treatment is effective in only half of patients infected with genotype $1 \mathrm{~b} \mathrm{HCV}$ with a high viral load. HCV dynamics at the early treatment phase is associated with treatment efficacy Peg-IFN and RBV combination therapy, and early suppression of viral replication is thought to be important. ${ }^{33}$ In addition, adverse effects and lower response rates can be a hindrance in the treatment of elderly patients. ${ }^{34}$ To solve these problems, screening with replicons is being used for the development of new anti-HCV agents to replace Peg-IFN and RBV in clinical practice.

$<$ Development of new treatments targeted at host factors $>$

Shimotohno et al. reported that cyclosporine A (CyA), 
an immunosuppressant widely used in clinical practice, suppressed HCV replication in the replicon system. ${ }^{35}$ This HCV replication suppression is not related with the cytotoxicity of CyA or the function as an immunosuppressant, but is a specific action of the replicon cells against HCV protein. The underlying mechanisms, binding to cyclophyllin and inhibition of peptidylprolyl isomerase enzyme activity, are thought to inhibit HCV replication. $^{36,37}$ It has been reported that CyA is effective against $\mathrm{HCV}$ in vivo, ${ }^{38,39}$ which has generated clinical interest. ${ }^{40}$

As mentioned previously, the HCV replication complex is created in the endoplasmic reticulum membrane, and an HCV life cycle is formed. It has been suggested that $\mathrm{HCV}$ replication can be regulated by targeting several molecules in the lipid raft, consisting of high-fluidity lipids such as saturated fatty acids, cholesterol and sphingomyelin, in the area of high-fluidity portion formed with unsaturated fatty acid bi-layered membrane. One study reported suppression of HCV replicon replication by myriocin, which interferes with the sphingomyelin synthesis pathway. ${ }^{41}$ In addition, it was reported that 3-hydroxy-3-methyl-glutaryl-CoA (HMG-CoA) reductase inhibitors suppress HCV replicon replication. ${ }^{42}$

$<$ Development of new treatments targeted at viral factors $>$

The development of new drugs targeted at NS3 encoding serine protease involved in viral replication ${ }^{38}$ and NS5B encoding RNA polymerase ${ }^{43}$ is another strategy that has been pursued. These drugs, which are expected to directly exert antiviral activity, referred to as specifically-targeted antiviral therapies (STATCs). It has been reported that serine protease activity encoded by NS3 inhibits not only the processing of viral protein but also IFN signal transduction ${ }^{44}$, and clinical trials are ongoing for clinical application of drugs targeted at this site. VX950 45,46 and SCH503034 77,48 are among the NS3 protease inhibitors under development. Since HCV is highly mutatable, monotherapy using one of these drugs results in immediate appearance of a resistant clone. ${ }^{49,50}$ Therefore, clinical trials on VX950 with or without IFN and in combination with RBV are ongoing in the U.S. and European countries. Similarly, clinical trials of SCH503034 with and without IFN are underway in patients refractory to a combination of Peg-IFN- $\alpha 2 b$ and RBV.

NM283, an RNA-dependent RNA polymerase inhibitor, was found to be effective in chimpanzees and cultured cells. However, since monotherapy with this agent was not fully effective, combination with IFN was required and as a result, adverse effects due to high-dose administration were reported. ${ }^{51,52}$

Since toll-like receptor 9 agonists likely exert antiviral activity by enhancing intrinsic IFN production, their ad- ministration in combination with Peg-IFN and RBV improved early virological response rates. ${ }^{53}$ Moreover, inhibition of HCV replicon with siRNA has been reported. ${ }^{54}$ Treatment with ribozyme and antisense oligonucleotides seems to be effective in replicons, however, because of issues with stability and drug delivery, they have not yet been sufficiently developed for clinical use as anti-HCV agents.

Table 1 summarized several treatment targets and ongoing preclinical and clinical trials.

\section{Regulation of Host Genes by HCV Protein}

To date, it has been reported that viral proteins, such as $\mathrm{E} 1 \mathrm{~A}^{55}$ and $\mathrm{E} 1 \mathrm{~B}^{56}$ of adenovirus, human immunodeficiency virus type 1 Tat protein, ${ }^{57}$ HTLV-1 Tax protein, ${ }^{58}$ human papilloma virus $\mathrm{E} 6^{59}$ and $\mathrm{E} 7^{60}$ protein, regulate transcriptional activity of host cells by influencing transcription regulating factors such as $\mathrm{CBP} / \mathrm{p} 300, \mathrm{PCAF}$, histone deacetylase complex, and SRC-1. On the other hand, it has been reported that HCV core protein upregulates transcription of retinoic acid receptor- $\alpha$ (RAR- $\alpha$ ) by isolating Sp110b, a transcriptional inhibitor of RAR- $\alpha$, from intranuclear space to the surface of endoplasmic reticulum. ${ }^{61}$ RAR- $\alpha$ is known as a receptor for retinoic acid-induced apoptosis. Similarly, it is possible that HCV protein regulates various other host genes.

\section{$\mathrm{HCV}$ and Carcinogenesis (Rb gene and HCV)}

The precise mechanism underlying the development from HCV infection to carcinogenesis has not been elucidated, but a relationship with several oncogenes has been proposed. Unlike hepatitis B virus (HBV), integration of the HCV gene into host cell DNA has not been recognized. Therefore, there are possibilities that $\mathrm{HCV}$ protein produced by $\mathrm{HCV}$ infection affects functions of host cells and heightens carcinogenicity.

Resent studies have revealed that HCV infection affects the cell cycle regulating protein $\mathrm{Rb}$. $\mathrm{Rb}$ protein affects cells in the G1-S phase ${ }^{62}$ and inhibits transcription factor E2F. ${ }^{63}$ In addition, the protein is well known as a tumor suppressor gene, and mutation in the Rb gene has been reported in lung and ovarian cancer cells. ${ }^{64,65} \mathrm{We}$ reported that the $\mathrm{Rb}$ gene bound to a specific site in the NS5B-encoding polymerase required for HCV replication, which suppressed the expression of $\mathrm{Rb}$ protein. ${ }^{66}$ The HCV sequence for binding was the same as the sequence previously reported in adenovirus ${ }^{67}$ and papilloma virus ${ }^{68}$ that bound the $\mathrm{Rb}$ gene. ${ }^{69}$ These oncogenes are thought to inhibit $\mathrm{Rb}$ gene function and the $\mathrm{LxCxE}$ motif by directly binding with them (Fig. 4 and 5), which suggests the involvement of $\mathrm{HCV}$ in carcinogenesis. 
Table 1 Targets of therapy and emerging therapies in HCV

\begin{tabular}{|c|c|c|}
\hline Target at viral factors & $\begin{array}{l}\text { Virus entry } \\
\text { Post translation processing } \\
\text { HCV replication } \\
\text { HCV RNA translation }\end{array}$ & $\begin{array}{l}\text { anti E2monoclonal antibody } \\
\text { HCV-AB(XTL)68 } \\
\text { NS3/4A serine protease inhibitors } \\
\text { VX950 (Telaprevir; phase 2), SCH503034 } \\
\text { (Boceprevir; phase 2), ITMN-191 (phase 1) } \\
\text { NS5B RNA dependent RNA polymerase inhibitors } \\
\text { (a) nucleoside analogues } \\
\text { NM283 (Valopicitabine; phase 2), R1626 (prodrug ofR1479; } \\
\text { phase 2), MK-608 (preclinical), R1656, R7128 (preclinical) } \\
\text { (b) non-nucleoside analogues } \\
\text { HCV-796 (phase 2), BILB1941 (phase 1), A-837093 } \\
\text { (preclinical), GS-9190 (phase 1) } \\
\text { NS5A inhibitors } \\
\text { A-831 (phase 1), A-689 (preclinical) } \\
\text { ribozyme } \\
\text { antisense oligonucleotide } \\
\text { siRNA }\end{array}$ \\
\hline Target at host factors & $\begin{array}{l}\text { Virus entry } \\
\text { Replication } \\
\text { Production of IFN } \\
\text { Virus particle release }\end{array}$ & $\begin{array}{l}\text { hepatitis C immunoglobulin } \\
\text { Civacir } \\
\text { Cyclosporin inhibitors } \\
\text { DEBIO-25 (phase 1), NIM811 (preclinical) } \\
\text { Myoricin, } \\
\text { HMG-CoA reductase inhibitors } \\
\text { TLR9 agonist } \\
\text { ER glucosidase inhibitors } \\
\text { Celgosivir (preclinical) }\end{array}$ \\
\hline
\end{tabular}

In addition of these therapies, several interferons have been on going as clinical studies (Albinterferon; phase 3, Pegamax; phase 1, Locteron; phase 1/2, Omega interferon; phase 2).

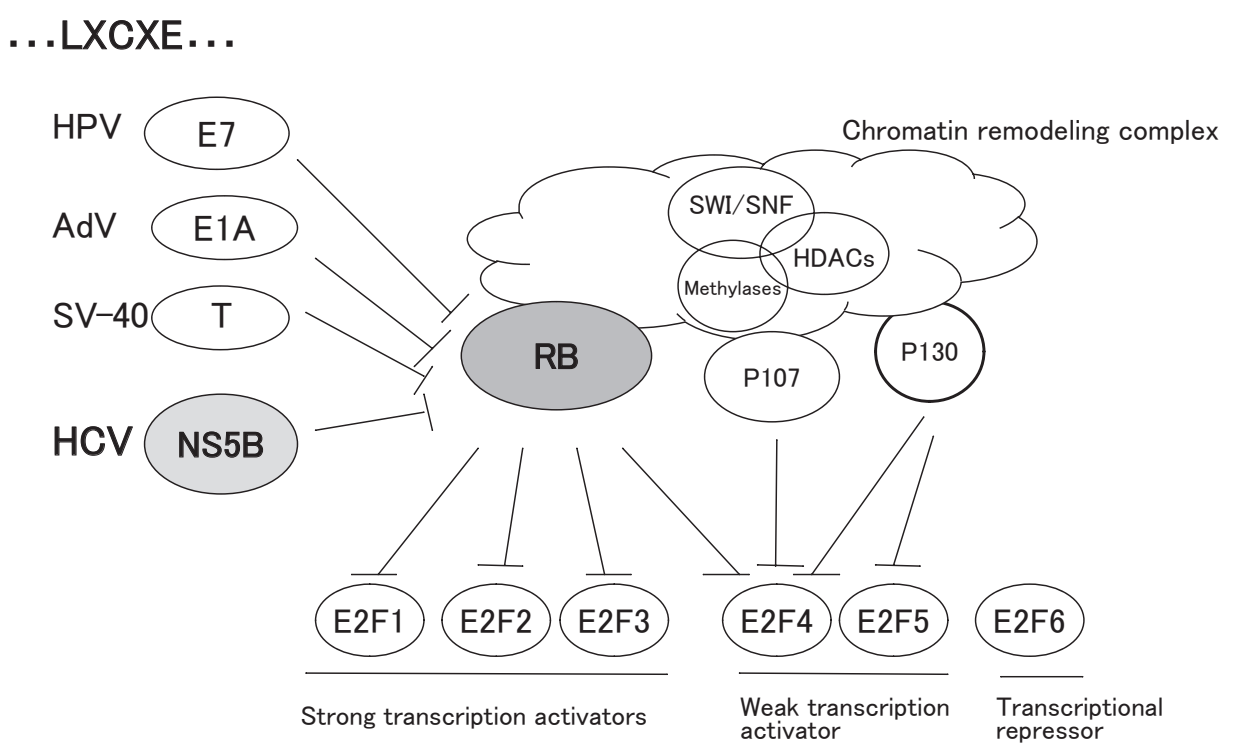

Fig. 4 Various viruses which regulate $\mathrm{Rb}$ gene and E2Fgene. $\mathrm{Rb}$ protein binds to a transcriptional factor E2F and inhibits its transcriptional activity. There are 6 kinds of E2F proteins in mammal genome, and they are divided into 3 categories depending to their transcriptional activity. Rb protein inhibits high active E2F1, E2F2 and E2F3. This E2F-dependent transcriptional inhibition of Rb protein is regulated by chromatin remodeling complex such as SWI/SNF complex, histone deacetylase polycomb group and methylase. Papilloma virus, adenovirus and SV40 T antigen also attenuate Rb protein-induced E2F inhibition. HDACs: histone deacetylases 


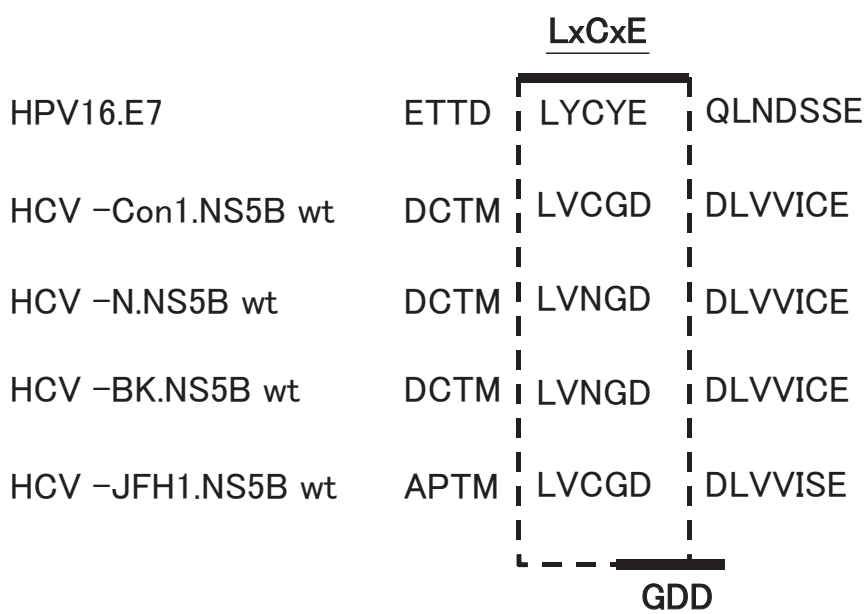

Fig. 5 Molecular mimicry of amino acids between papilloma virus and $\mathrm{HCV}$. LxCxE domain of human papilloma virus E7 protein and 314-318 amino acids alignment of NS5B region of HCV (Con 1 strain and $\mathrm{N}$ strain). This region of HCV contains GDD sequence necessary for viral polymerase activity.

\section{Conclulsion}

The aim of HCV eradication is to eventually reduce the occurrence of HCC. It is therefore important to elucidate the mechanisms by which $\mathrm{HCV}$ infection precipitates the onset of HCC. Clinical research in the past years has focused on the improvement of IFN-based treatment regimens. HCV-specific antiviral compounds, some of which have been developed by investigation using the replicon system, are a new perspective in the treatment of chronic hepatitis C. Since the viral RNA-polymerase possesses a high error rate, $\mathrm{HCV}$ variants are continuously produced during replication, and selection of drug-resistant $\mathrm{HCV}$ strains may occur when viral replication continues. On the other hand, innate and adaptive immune response play an important role in the control of $\mathrm{HCV}$ infection, but these responses are hampered by several mechanisms in HCV infection, resulting a weak immunologic response for complete elimination of HCV infected hepatocytes. The replicon system is not a sufficient tool for investigating such an immunological mechanism. A potentially safe and stronger treatment for chronic hepatitis $\mathrm{C}$ by combination of several drugs with different mechanisms is expected especially in Japan, where the patients is becoming older, and in vitro replicon system will be still expected to produce a useful information for making a new drug design.

\section{References}

1. Kato N, Hijikata M, Ootsuyama Y, Nakagawa M, Ohkoshi S, Sugimura T, Shimotohno K: Molecular cloning of the human hepatitis $\mathrm{C}$ virus genome from Japanese patients with non-A, non-B hepatitis. Proc Natl Acad Sci U S A 1990; 87: 9524-9528

2. Tanaka T, Kato N, Cho MJ, Shimotohno K: A novel sequence found at the 3' terminus of hepatitis $\mathrm{C}$ virus genome. Biochem Biophys Res Commun 1995; 215: 744-749

3. Manns MP, McHutchison JG, Gordon SC, Rustgi VK, Shiffman M, Reindollar R, Goodman ZD, Koury K, Ling M, Albrecht JK: Peginterferon alfa- $2 \mathrm{~b}$ plus ribavirin compared with interferon alfa- $2 \mathrm{~b}$ plus ribavirin for initial treatment of chronic hepatitis $\mathrm{C}$ : $\mathrm{a}$ randomised trial. Lancet 2001; 358: 958-965

4. Kumagai N, Kaneko F, Tsunematsu S, Tsuchimoto K, Tada S, Saito H, Hibi T: Complexity of the HVAR-1 quasispecies and disease activity in patients with hepatitis C. Eur J Clin Invest 2007; 37: $566-572$

5 N Enomoto, I Sakuma, Y Asahina, M Kurosaki, T Murakami, C Yamamoto, N Izumi, F Marumo, C Sato: Comparison of fulllength sequences of interferon-sensitive and resistant hepatitis $\mathrm{C}$ virus $1 \mathrm{~b}$. Sensitivity to interferon is conferred by amino acid substitutions in the NS5A region. J Clin Invest 1995; 96: 224-230

6 Enomoto N, Sakuma I, Asahina Y, Kurosaki M, Murakami T, Yamamoto C, Ogura Y, Izumi N, Marumo F, Sato C: Mutations in the nonstructural protein $5 \mathrm{~A}$ gene and response to interferon in patients with chronic hepatitis $\mathrm{C}$ virus $1 \mathrm{~b}$ infection. $\mathrm{N}$ Engl J Med 1996; 334: 77-81

7 Watanabe H, Nagayama K, Enomoto N, Itakura J, Tanabe Y, Hamano K, Izumi N, Sato C, Watanabe M: Sequence elements correlating with circulating viral load in genotype $1 \mathrm{~b}$ hepatitis $\mathrm{C}$ virus infection. Virology 2003; 311: 376-383

8 Choo QL, Kuo G, Weiner AJ, Overby LR, Bradley DW, Houghton $\mathrm{M}$ : Isolation of a cDNA clone derived from a blood-borne non-A, non-B viral hepatitis genome. Science 1989; 244: 359362

9 Kolykhalov AA, Agapov EV, Blight KJ, Mihalik K, Feinstone SM, Rice CM: Transmission of hepatitis $\mathrm{C}$ by intrahepatic inoculation with transcribed RNA. Science 1997; 277: 570-574

10 Lohmann V, Korner F, Koch J, Herian U, Theilmann L, Bartenschlager R: Replication of subgenomic hepatitis $C$ virus RNAs in a hepatoma cell line. Science 1999; 285: 110-113

11 Kishine H, Sugiyama K, Hijikata M, Kato N, Takahashi H, Noshi T, Nio Y, Hosaka M, Miyanari Y, Shimotohno K: Subgenomic replicon derived from a cell line infected with the hepatitis $\mathrm{C}$ virus. Biochem Biophys Res Commu 2002; 293: 993-999

12 Blight KJ, McKeating JA, Marcotrigiano J, Rice CM: Efficient replication of hepatitis $\mathrm{C}$ virus genotype 1a RNAs in cell culture. J Virol 2003; 77: 3181-3190

13 Kato T, Date T, Miyamoto M, Furusaka A, Tokushige K, Mizokami M, Wakita T: Efficient replication of the genotype 2a hepatitis c virus subgenomic replicon. Gastroenterology 2003; 125: 18081817

14 Ikeda M, Yi M, Li K, Lemon SM: Selectable subgenomic and genome-length dicistronic RNAs derived from an infectious molecular clone of the HCV-N strain of hepatitis $\mathrm{C}$ virus replicate efficiently in cultured Huh7 cells. J Virol 2002; 76: 2997-3006.

15 Lohmann V, Korner F, Dobierzewska A, Bartenschlager R: Mutations in hepatitis $\mathrm{C}$ virus RNAs conferring cell culture adaptation. J Virol 2001; 75: 1437-1449

16 Kumagai N, Takahashi N, Kinoshita M, Tsunematsu S, Tsuchimoto K, Saito H, Ishii H, Hibi T: Polymorphism of NS5B protein relates to early clearance of hepatitis $\mathrm{C}$ virus by interferon plus ribavirin: a pilot study. J Viral Hepat 2004; 11: 225-235

17 Nakamura M, Saito H, Ikeda M, Tada S, Kumagai N, Kato N, Shimotohno K, Hibi T: Possible molecular mechanism of the re- 
lationship between NS5B polymorphisms and early clearance of hepatitis $\mathrm{C}$ virus during interferon plus ribavirin treatment. J Med Virol 2008; 80: 632-639

18 Blight KJ, McKeating JA, Marcotrigiano J, Rice CM: Efficient replication of hepatitis $\mathrm{C}$ virus genotype 1a RNAs in cell culture. J Virol 2003; 77: 3181-3190

19 Pietschmann T, Lohmann V, Kaul A, Kriegeerr N, Rinck G, Rutter G, Strand D, Bartenschlager R: Persistent and transient replication of full-length hepatitis $\mathrm{C}$ virus genomes in cell culture. $\mathrm{J}$ Virol 2002; 76: 4008-4021

20 Lindenbach BD, Evans MJ, Syder AJ, Wolk B, Tellinghuisen TL, Liu CC, Maruyama T, Hynes RO, Burton DR, McKeating JA, Rice CM: Complete replication of hepatitis $\mathrm{C}$ virus in cell culture. Science 2005; 309: 623-626

21 Tscherne DM, Jones CT, Evans MJ, Lindenbach BD, McKeating JA, Rice CM: Time- and temperature-dependent activation of hepatitis $\mathrm{C}$ virus for low-pH-triggered entry. J Virol 2006; 80: $1734-1741$

22 Randall G, Chen L, Panis M, Fischer AK, Lindenbach BD, Sun J, Heathcote J, Rice CM: Silencing of UPD18 potentiates the antiviral activity of interferon against hepatitis $\mathrm{C}$ virus infection. Gastroenterology 2006; 131: 1584-1591

23 Schwer B, Ren S, Pietschmann T, Kartenbeck J, Kaehicke K, Bartenschlager R, Yen TS, Ott M: Targeting of hepatitis C virus core protein to mitochondria through a novel C-terminal localization motif. J Virol 2004; 78: 7958-7968

24 Lee SH, Kim YK, Kim CS, Seol SK, Kim J, Cho S, Song YL, Bartenschlager R, Jang SK: E2 of hepatitis C virus inhibits apoptosis. J Immunol 2005; 175: 8226-8235

25 Miyanari Y, Hijikata M, Yamaji M, Hosaka M, Takahashi H, Shimotohno $\mathrm{K}$ : Hepatitis $\mathrm{C}$ virus non-structural proteins in the probable membranous compartment function in viral genome replication. J Biol Chem 2003; 278: 50301-50308

26 Gosert R, Egger D, Lohmann V, Bartenschlager R, Blum HE, Bienz $\mathrm{K}$, Moradpour D: Identification of the hepatitis $\mathrm{C}$ virus RNA replication complex in Huh-7 cells harboring subgenomic replicons. J Virol 2003; 77: 5487-5492

27 Schwartz M, Chen J, Janda M, Sullivan M, den Boon J, Ahlquist $\mathrm{P}$ : A positive-strand RNA virus replication complex parallels form and function of retrovirus capsids. Mol Cell 2002; 9: 505-514

28 Kato T, Date T, Miyamoto M, Furusaka A, Tokushige K, Mizokami M, Wakita T: Efficient replication of the genotype 2a hepatitis C virus subgenomic replicon. Gastroenterology 2003; 125: 1808 $-1817$

29 Wakita T, Pietschmann T, Kato T, Date T, Miyamoto M, Zhao Z, Murthy K, Habermann A, Krausslich HG, Mizokami M, Bartenschlager R, Liang TJ: Production of infectious hepatitis C virus in tissue culture from a cloned viral genome. Nat Med 2005; 11: $791-796$

30 Zhong J, Gastaminza P, Cheng G, Kapadia S, Kato T, Burton DR, Wieland SF, Uprichard SL, Wakita T, Chisari FV: Robust hepatitis C virus infection in vitro. Proc Natl Acad Sci U S A 2005; 102 : 9294-9299

31 Lindenbach BD, Evans MJ, Syder AJ, Wolk B, Tellinghuisen TL, Liu CC, Maruyama T, Hynes RO, Burton DR, McKeating JA, Rice CM: Cell culture-grown hepatitis $\mathrm{C}$ virus is infectious in vivo and can be recultured in vitro. Proc Natl Acad Sci U S A 2006; 103: 3805-3809

32 Morikawa K, Xhao Z, Date T, Miyamoto M, Murayama A, Akazawa D, Tanabe J, Sone S, Wakita T: The role of CD81 and glycosaminoglycans in the adsorption and uptake of infectious HCV particles. J Med Virol 2007; 79: 714-723

33 Takahashi M, Saito H, Higashimoto M, Atsukawa K, Ishii H: Benefit of hepatitis $\mathrm{C}$ virus core antigen assay in prediction of therapeutic response to interferon and ribavirin combination therapy. J Clin Microbiol 2005; 43: 186-191

34 Saito H, Tada S, Ebinuma H, Ishii H, Kashiwazaki K, Takahashi
M, Tsukada N, Nishida J, Tanaka S, Shiozaki H, Hibi T: Role of erythrocytes as a reservoir for ribavirin and relationship with adverse reactions in the early phase of interferon combination therapy for chronic hepatitis C virus infections. J Clin Microbiol 2006; 44:3562-3568

35 Watashi K, Hijikata M, Hosaka M, Yamaji M, Shimotohno K: Cyclosporin A suppresses replication of hepatitis $\mathrm{C}$ virus genome in cultured hepatocytes. Hepatology 2003; 38:1282-1288

36 Loor F, Tiberghien F, Wenandy T, Didier A, Traber R: Cyclosporins: structure-activity relationships for the inhibition of the human MDR1 P-glycoprotein ABC transporter. J Med Chem 2002; 45: $4598-4612$

37 Ye J, Wang C, Sumpter R, Jr., Brown MS, Goldstein JL, Gale M, Jr: Disruption of hepatitis C virus RNA replication through inhibition of host protein geranylgeranylation. Proc Natl Acad Sci U S A 2003; 100: 15865-15870

38 Inoue K, Sekiyama K, Yamada M, Watanabe T, Yasuda H, Yoshiba M: Combined interferon $\alpha 2 \mathrm{~b}$ and cyclosporin $\mathrm{A}$ in the treatment of chronic hepatitis C: controlled trial. J Gastroenterol 2003; 38: $567-572$

39 Akiyama H, Yoshinaga H, Tanaka T, Hiruma K, Tanikawa S, Sakamaki H, Onozawa Y, Wakita T, Kohara M: Effects of cyclosporin $\mathrm{A}$ on hepatitis $\mathrm{C}$ virus infection in bone marrow transplant patients. Bone Marrow Transplantation Team. Bone Marrow Transplant 1997; 20: 993-995

40 Goto K, Watashi K, Murata T, Hishiki T, Hijikata M, SHimotohno $\mathrm{K}$ : Evaliation of the anti-hepatitis $\mathrm{C}$ virus effects of cyclophilin inhibitors, cyclosporine A, and NIM 811. Biochem Biophys Res Commun 2006; 343: 879-884

41 Umehara T, Sudoh M, Yasui F, Matsuda C, Hayashi Y, Chayama K, Kohara M: Serine palmitoyltransferase inhibitor suppresses HCV replication in a mouse model. Biochem Biophys Res Commun 2006; 346: 67-73

42 Ikeda M, Abe K, Yamada M, Dansako H, Naka K, Kato N: Different anti-HCV profiles of statins and their potential for combination therapy with interferon. Hepatology 2006; 44: 117-125

43 Lamarre D, Anderson PC, Bailey M, Beaulieu P, Bolger G, Bonneau P, Bos M, Cameron DR, Cartier M, Cordingley MG, Faucher AM, Goudreau N, Kawai SH, Kukolj G, Lagace L, LaPlante SR, Narjes H, Poupart MA, Rancourt J, Sentjens RE, St George R, Simoneau B, Steinmann G, Thibeault D, Tsantrizos YS, Weldon SM, Yong CL, Llinas-Brunet M: An NS3 protease inhibitor with antiviral effects in human $\mathrm{s}$ infected with hepatitis $\mathrm{C}$ virus. Nature 2003; 426: 186-189

44 Dhanak D, Duffy KJ, Johnston VK, Lin-Goerke J, Darcy M, Shaw AN, Gu B, Silverman C, Gates AT, Nonnemacher MR, Earnshaw DL, Casper DJ, Kaura A, Baker A, Greenwood C, Gutshall LL, Maley D, DelVecchio A, Macarron R, Hofmann GA, Alnoah Z, Cheng HY, Chan G, Khandekar S, Keenan RM, Sarisky RT: Identification and biological characterization of heterocyclic inhibitors of the hepatitis C virus RNA-dependent RNA polymerase. J Biol Chem 2002; 277: 38322-38327

45 Foy E, Li K, Wang C, Sumpter R, Ikeda M, Lemon SM, Gale M: Regulation of interferon regulatory factor- 3 by the hepatitis $\mathrm{C}$ virus serine protease. Science 2003; 300: 1145-1148

46 Reesink HW, Zeuzem S, Weegink CJ, Forestier N, van Vliet A, van de Wetering de Rooij J, McNair L, Purdy S, Kauffman R, Alam J, Jansen PL: Rapid decline of viral RNA in hepatitis C patients treated with VX-950: a phase $\mathrm{Ib}$, placebo-controlled, randomized study. Gastroenterology 2006; 131: 997-1002

47 Summa V. VX-950 (Vertex/Mitsubishi). Curr Opin Investig Drugs 2005; 8: 831-837

48 Sarrazin C, Rouzier R, Wagner F, Forestier N, Larrey D, Gupta SK, Hussain M, Shah A, Cutler D, Zhang J, Zeuzem S: SCH 503034, a novel hepatitis $C$ virus protease inhibitor, plus pegylated interferon alpha- $2 b$ for genotype 1 nonresponders. Gastroenterology 2007; 132: 1270-1278 
49 Perelson AS, Herrmann E, Micol F, Zeuzem S: New kinetic models for the hepatitis C virus. Hepatology 2005; 42: 749-754

50 Yi M, Tong X, Skelton A, Chase R, Chen T, Prongay A, Bogen SL, Saksena AK, Njoroge FG, Veselenak RL, Pyles RB, Bourne N, Malcolm BA, Lemon SM: Mutations conferring resistance to SCH6, a novel hepatitis C virus NS3/4A protease inhibitor. Reduced RNA replication fitness and partial rescue by second-site mutations. J Biol Chem 2006; 28: 8205-8215

51 Lin C, Gates CA, Rao BG, Brennan DL, Fulghum JR, Luong YP, Frantz JD, Lin K, Ma S, Wei YY, Perni RB, Kwong AD: In vitro studies of cross-resistance mutations against two hepatitis $\mathrm{C}$ virus serine protease inhibitors, VX-950 and BILN 2061. J Biol Chem 2005; 280: 36784-36791

52 Carroll SS, Olsen DB: Nucleoside analog inhibitors of hepatitis C virus replicationInfect. Disord Drug Targets 2006; 6: 17-29

53 Pierra C, Amador A, Benzaria S, Cretton-Scott E, D'Amours M, Mao J, Mathieu S, Moussa A, Bridges EG, Standring DN, Sommadossi JP, Storer R, Gosselin G: Synthesis and pharmacokinetics of valopicitabine (NM283), an efficient prodrug of the potent anti-HCV agent 2'-C-methylcytidine. J Med Chem 2006; 49: $6614-6620$

54 McHutchison J, Ghalib R, Lawitz E, Freilich B, Kwo P, Masciari F, Himes JL, Al-Adhami M, Bacon B: Early Viral Response to CpG 10101, a new investigational antiviral TLR9 agonist, in combination with pegylated interferon and/or ribavirin, in prior relapse $\mathrm{HCV}$ responders: preliminary report of a randomized phase 1 study. Gastroenterology 2006; 130: S1062

55 Yokota T, Sakamoto N, Enomoto N, Tanabe Y, Miyagishi M, Maekawa S, Yi L, Kurosaki M, Taira K, Watanabe M, Mizusawa $\mathrm{H}$ : Inhibition of intracellular hepatitis $\mathrm{C}$ virus replication by synthetic and vector-derived small interfering RNAs. EMBO reports 2003; 4, 6: 602-608

56 Arany Z, Newsome D, Oldread E, Livingston DM, Eckner R: A family of transcriptional adaptor proteins targeted by the E1A oncoprotein. Nature 1995; 374: $81-84$

57 Liu Y, April L. Colosimo AL, Yang XJ, Liao D: Adenovirus E1B 55-Kilodalton Oncoprotein Inhibits p53 Acetylation by PCAF. Mol Cell Biol 2000; 20: 5540-5553

58 Ariumi Y, Kaida A, Hatanaka M, Shimotohno K: Functional cross-talk of HIV-1 Tat with p53 through its C-terminal domain. Biochem Biophys Res Commun 2001; 287: 556-561
59 Ariumi Y, Kaida A, Lin JY, Hirota M, Masui O, Yamaoka S, Taya Y, Shimotohno K: HTLV-1 tax oncoprotein represses the p53-mediated trans-activation function through coactivator CBP sequestration. Oncogene 2000; 19: 1491-1499

60 Patel D, Huang SM, Baglia LA, McCance DJ: The E6 protein of human papillomavirus type 16 binds to and inhibits co-activation by CBP and p300. EMBO J 1999; 18: 5061-5072

61 Park JS, Kim EJ, Kwon HJ, Hwang ES, Namkoong SE, Um SJ: Inactivation of interferon regulatory factor-1 tumor suppressor protein by HPV E7 oncoprotein. Implication for the E7-mediated immune evasion mechanism in cervical carcinogenesis. J Biol Chem 2000; 275: 6764-6769

62 Watashi K, Hijikata M, Tagawa A, Doi T, Marusawa H, Shimotohno K: Modulation of retinoid signaling by a cytoplasmic viral protein via sequestration of $\mathrm{Sp} 110 \mathrm{~b}$, a potent transcriptional corepressor of retinoic acid receptor, from the nucleus. Mol Cell Biol 2003; 23: 7498-7509

63 Edamoto Y, Hara A, Biernat W, Terracciano L, Cathomas G, Riehle HM, Matsuda M, Fujii H, Scoazec JY, Ohgaki H: Alterations of RB1, p53 and Wnt pathways in hepatocellular carcinomas associated with hepatitis $\mathrm{C}$, hepatitis $\mathrm{B}$ and alcoholic liver cirrhosis. Int J Cancer 2003; 106: 334-341

64 Chellappan SP, Hiebert S, Mudryj M, Horowitz JM, Nevins, JR: The E2F transcription factor is a cellular target for the RB protein. Cell 1991; 65: 1053-1061

65 Chau BN, Wang JY: Coordinated regulation of life and death by RB. Nat Rev Cancer 2003; 3: 130-138

66 Munakata T, Nakamura M, Liang Y, Li K, Lemon SM: Downregulation of the retinoblastoma tumor suppressor by the hepatitis C virus NS5B RNA-dependent RNA polymerase. Proc Natl Acad Sci USA 2005; 102: 18159-18164

67 Whyte P, Buchkovich KJ, Horowitz JM, Friend SH, Raybuck M, Weinberg RA, Harlow E: Association between an oncogene and an anti-oncogene: the adenovirus E1A proteins bind to the retinoblastoma gene product. Nature 1988; 334: 124-129

68 Dyson N, Howley PM, Munger K, Harlow E: The human papilloma virus-16 E7 oncoprotein is able to bind to the retinoblastoma gene product. Science 1989; 243: 934-937

69 Lee JO, Russo AA, Pavletich NP: Structure of the retinoblastoma tumour-suppressor pocket domain bound to a peptide from HPV E7. Nature 1998; 391: 859-865 